\title{
RESPON MAHASISWA TERHADAP PENYELESAIAN SOAL KONEKSI MATEMATIS MELALUI TAKSONOMI FINK
}

\author{
Kanisius Mandur ${ }^{1}$, Fransiskus Nendi ${ }^{2}$, Fulgensius Efrem Men ${ }^{3}$, Silfanus Jelatu ${ }^{4}$ \\ 1,2,3,4 Program Studi Pendidikan Matematika, Unika Santu Paulus Ruteng \\ Email: ${ }^{1}$ kanisiusmandur@gmail.com, ${ }^{2}$ fransiskusnendi@gmail.com, ${ }^{3}$ efrem.math@gmail.com, \\ ${ }^{4}$ djelatusilfanus@gmail.com
}

\begin{abstract}
ABSTRAK
Respon mahasiswa merupakan aspek penting dalam pembelajaran, karena membantu pendidik untuk memahami perkembangannya. Salah satu kerangka yang digunakan menganalisis respon mahasiswa pada aspek kognitif, afektif, maupun metakognitif yaitu taksonomi Fink. Penelitian ini betujuan menemukan pola tingkat respon mahasiswa dalam menyelesaikan soal koneksi matematis melalui taksonomi Fink. Metode penelitian ini yaitu metode kualitatif. Data yang dikumpulkan yaitu data kemampuan koneksi matematis untuk mengukur respon mahasiswa pada aspek kognitif dan metakognitif yang diambil dengan menggunakan instrumen tes serta data dimensi sosial dan kepedulian untuk mengukur respon mahasiswa pada aspek afektif yang ambil dengan menggunakan angket. Data penelitian ini dikumpulkan pada bulan januari dan Februari tahun 2020 pada mahasiswa tingkat 3B program studi pendidikan Matematika Universitas Katolik Indonesia Santu Paulus yang berjumlah 20 orang. Hasil penelitian ini yaitu respon mahasiswa pada level pengetahuan dasar sebesar 18,42\%, aplikasi sebesar 12,79\%, integrasi sebesar $12,22 \%$, dimensi sosial 23,28\%, aspek kepedulian sebesar $22,34 \%$ serta metakognitif sebesar $10,95 \%$ dan hasil respon mahasiswi pada level pengetahuan dasar sebesar $18,94 \%$, aplikasi sebesar $13,16 \%$, integrasi sebesar $11,23 \%$, dimensi sosial $23,87 \%$, aspek kepedulian sebesar 22,78\% dan metakognitif sebesar 10,02\%. Respon mahasiswa pada aspek kognitif, afektif, maupun metakognitif memberikan gambaran bagi pendidik agar memperhatikan kemampuan dan sikap siswa dalam membangun pengetahuan secara mandiri pada suatu materi pelajaran.
\end{abstract}

Kata Kunci: Respon Mahasiswa, Taksonomi Fink, \& Koneksi Matematis

\begin{abstract}
Student response is an important aspect of learning because it helps educators understand student development. One of the frameworks used to analyze student responses to cognitive, affective, and metacognitive aspects is the Fink taxonomy. This study aims to find patterns of student response rates in solving mathematical connection through Fink's taxonomy. This research method is qualitative. The data collected were data on the ability of mathematical connections to measure student responses to cognitive and metacognitive aspects taken using test instruments as well as data on social and caring dimensions to measure student responses to affective aspects that were taken using questionnaires. This research data was collected in January and February 2020 on 20 students of the 3B level of the Mathematics education study program at Saint Paulus University of the Catholic Indonesia. The results of this study are student responses at the basic knowledge level of $18.42 \%$, application of $12.79 \%$, integration of $12.22 \%$, social dimensions $23.28 \%$, caring aspects of $22.34 \%$, and metacognitive 10.95 . \% and student response results at the level of basic knowledge of $18.94 \%$, application of $13.16 \%$, integration of $11.23 \%$, social dimensions $23.87 \%$, caring aspects of $22.78 \%$, and metacognitive of $10.02 \%$. Student responses to cognitive, affective, and metacognitive aspects provide an overview for educators to pay attention to students' abilities and attitudes in building knowledge independently on a subject matter.
\end{abstract}


Keywords: Student Response, Fink Taxonomy, \& Mathematical Connections

\section{PENDAHULUAN}

Belajar merupakan kegiatan sosial dan kultural tempat peserta didik mengonstruksikan makna yang dipengaruhi oleh interaksi antara pengetahuan sebelumnya dan peristiwa belajar baru (Arends, 2008). Kegiatan belajar tidak hanya difokuskan pada peserta didik yang berusaha memahami sebuah fenomena, tetapi juga peran sosial dalam pembelajaran. Kegiatan pembelajaran di kelas melibatkan interaksi pendidik dan peserta didik agar lebih berkualitas. Interaksi tersebut dapat berupa tanggapan atau respon yang diberikan peserta didik terhadap pendidik atau dari pendidik terhadap peserta didik. Respon merupakan gerakan yang terkoordinasi oleh persepsi seseorang terhadap peristiwa-peristiwa yang terjadi di lingkungan sekitar (Hamalik, 2011) sedangkan menurut kamus psikologi respon merupakan proses otot yang muncul akibat rangsangan dalam bentuk jawaban atau tingkah laku (Chaplin, 2004). Jawaban dapat muncul sebagai hasil dari tes atau angket dan tingkah laku dapat berupa perubahan baik yang terlihat maupun yang tersembunyi pada individu (Simanjutak \& Imelda, 2018). Pengetahuan tentang respon peserta didik sangat penting bagi pendidik terutama dalam kemampuan berpikir matematis agar mendapatkan gambaran yang baik pada aspek kognitif, afektif, psikomotorik maupun metakognitif sehingga pendidik dapat melakukan tindak lanjut dengan merencanakan dan melaksanakan pembelajaran yang berkualitas untuk mencapai tujuan pembelajaran yang diharapkan.

Berpikir matematika merupakan kegitan mental yang melibatkan proses abstraksi dan atau generalisasi (Hudojo, 1988). Pengetahuan mengenai respon peserta didik sebagai upaya meningkatkan kemampuan berpikir matematis (Ekawati, dkk, 2013). Pemahaman terhadap respon peserta didik memerlukan kemampuan pendidik mengidentifikasi dan menganalisis respon peserta didik sebagai akibat proses pendidikan dan kemampuan pendidik untuk melakukan tindak lanjut berdasarkan hasil respon peserta didik menuju pencapaian target pembelajaran (Suryadi \& Tarmudi, 2011). Namun, beberapa kendala dalam mengembangkan dan meningkatkan kemampuan berpikir matematis yaitu standar kompetensi dan kompetensi dasar tuntutannya terlalu banyak yang harus dicapai, menekankan hasil daripada proses, dan bentuk soal menekankan kemampuan prosedural yang tidak sesuai dengan kemampuan berpikir matematis (Wijaya, 2012).

Dosen merupakan pendidik profesional dituntut untuk menggunakan praktik terbaik untuk membantu mahasiswa mempelajari pengetahuan, keterampilan, dan sikap yang esensial, sehinga pengetahuan dan pemahaman terhadap respon mahasiswa sangat penting. Salah satu kerangka acuan yang digunakan untuk menganalisis respon mahasiswa adalah taksonomi Fink. Respon mahasiswa melalui taksonomi Fink mencakup kognitif dan afektif. Taksonomi Fink merupakan taksonomi yang diciptakan oleh L. Dee Fink pada tahun 2003. Taksonomi Fink mengacu pada enam aspek yaitu foundational knowledge (pengetahuan dasar), application (aplikasi), integration (integrasi), human dimension (dimensi sosial), caring (rasa peduli), dan learning how to learn (belajar untuk belajar) sebagai domain metakognitif.

Respon mahasiswa yang diteliti dalam penelitian ini yaitu respon mahasiswa dalam menyelesaikan soal-soal koneksi matematis pada mata kuliah masalah nilai awal. Mata kuliah masalah nilai awal merupakan lanjutan dari mata kuliah persamaan diferensial yang menuntut mahasiswa memiliki kemampuan koneksi matematis. Perkembangan ilmu pengetahahuan dan teknologi (IPTEK) yang sangat pesat menuntut manusia untuk memiliki kemampuan pemecahan masalah dan kemampuan berpikir lintas ilmu pengetahuan, sehingga manusia dituntut untuk memiliki kemampuan konektivitas. Hal ini sejalan dengan Wagner (2012) mengidentifikasi kompetensi dan keterampilan bertahan hidup yang diperlukan dalam 
menghadapi kehidupan, dunia kerja, dan kewarganegaraan di abad ke-21 yaitu kemampuan berpikir kritis, memecahkan masalah, kemampuan mengakses dan menganalisis informasi, serta dituntut untuk memiliki daya imajinasi yang tinggi. Kemampuan dan keterampilan tersebut diasah dan dilatih melalui kemampuan melakukan koneksi matematis. Kemampuan koneksi matematis adalah kemampuan untuk menghubungkan inter topik dan antar topik dalam matematika, menghubungkan matematika dengan bidang lain, atau matematika dengan masalah dalam kehidupan sehari-hari. Namun, hasil penelitian menunjukkan bahwa kemampuan matematis peserta didik masih tergolong rendah (Linto, 2012; Ramdani, 2012). Rendahnya kemampuan koneksi matematis dapat disebabkan oleh beberapa faktor baik ekternal seperti metode pembelajaran yang digunakan pendidik atau dosen, bahan ajar, media pembelajaran atau faktor internal seperti motivasi dan ketertarikan mahasiswa terhadap materi pembelajaran. Oleh karena itu evaluasi terhadap proses pembelajaran sangat dibutuhkan. Evaluasi tersebut selain dilakukan oleh dosen juga memerlukan evaluasi dari mahasiswa. Salah satu cara untuk mengevaluasi baik tidaknya proses pembelajaran selama perkuliahan dapat dilihat dari respon mahasiswa. Respon mahasiswa tersebut menunjukkan kepuasan dan ketercapaian tujuan pembelajaran. Kemudian hasil evaluasi dari respon mahasiswa tersebut dapat digunakan untuk memperbaiki proses pembelajaran di dalam kelas.

\section{METODE}

Metode yang digunakan dalam penelitian ini yaitu metode dengan pendekatan kualitatif dalam menemukan bentuk respon mahasiswa dalam menyelesaikan soal koneksi matematis melalui taksonomi Fink. Prosedur dalam penelitian ini dibagi menjadi tiga tahap yaitu: (1) tahap persiapan, meliputi penyusunan instrumen baik instrument tes maupun angket; (2) tahap pelaksanaan untuk mengumpulkan data penelitian, pada tahap ini instrumen tes yang sudah divalidasi selanjutnya diberikan kepada setiap mahasiswa tingkat 3B yang mendapatkan mata kuliah masalah nilai awal. Mahasiswa dikelompokkan dalam dua kelompok yaitu kelompok mahasiswa dan kelompok mahasiswi. Pengambilan data dilakukan dalam dua kali tes yaitu tes pertama yaitu tes untuk materi persamaan diferensial dan tes kedua yaitu tes untuk masalah nilai awal serta angket pertama dan kedua untuk mendapatkan data respon mahasiswa pada dimensi sosial danpeduli. Selanjutnya mahasiswa dan mahasiswi diwawancara dan dipilih berdasarkan informasi dari dosen yang dapat mengkomunikasikan pendapat baik secara lisan maupun tulisan; (3) tahap pemaparan dimana hasil analisis respon mahasiswa dan hasil wawancara dipaparkan dan digunakan untuk mendeskripsikan level respon mahasiswa. Prosedur penelitian ini dapat dilihat pada diagram alir berikut ini: 


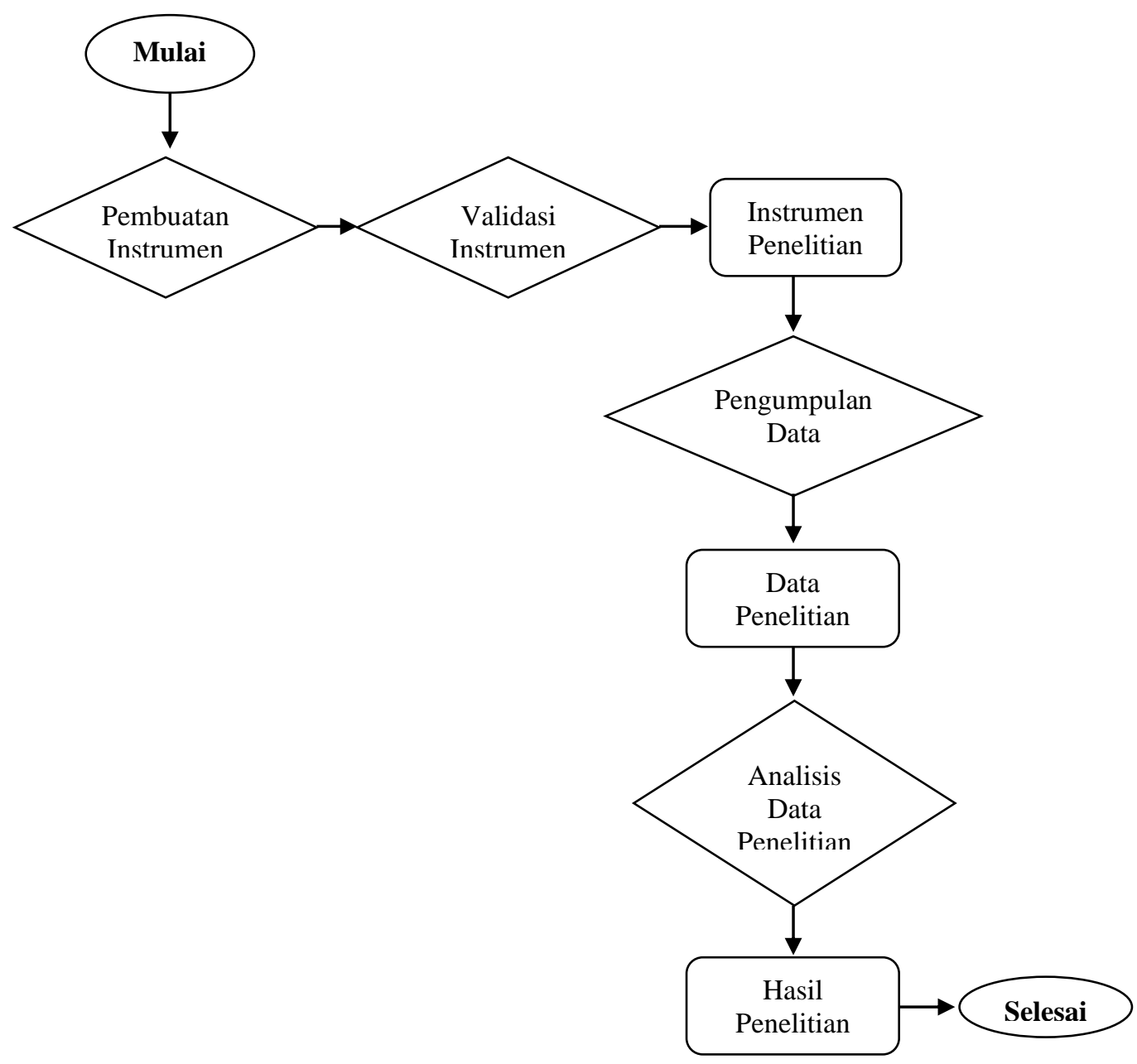

Diagram 1: Prosedur Penelitian

Data yang dikumpulkan dalam penelitian ini yaitu data yang berkaitan dengan respon kognitif dan metakognitif yang dikumpulkan dengan teknik tes dan data yang beraitan dengan afektif yang dikumpulkan melalui angket dan kemudian dikonfirmasi dengan menggunakan dengan metode wawancara. Data yang dihasilkan yaitu hasil jawaban soal dan angket mahasiswa dan data hasil wawancara. Triangulasi dilakukan untuk mengecek keabsahan data. Instrumen pegumpulan data yang digunakan yaitu peneliti, soal tes koneksi matematis untuk level kognitif dan metakognitif serta angket untuk level afektif. Level respon pebelajar melalui taksonomi Fink (Latifah, 2017) dapat dilihat pada Tabel 1 berikut:

Tabel 1. Indikator Respon Mahasiswa Berdasarkan Taksonomi Fink

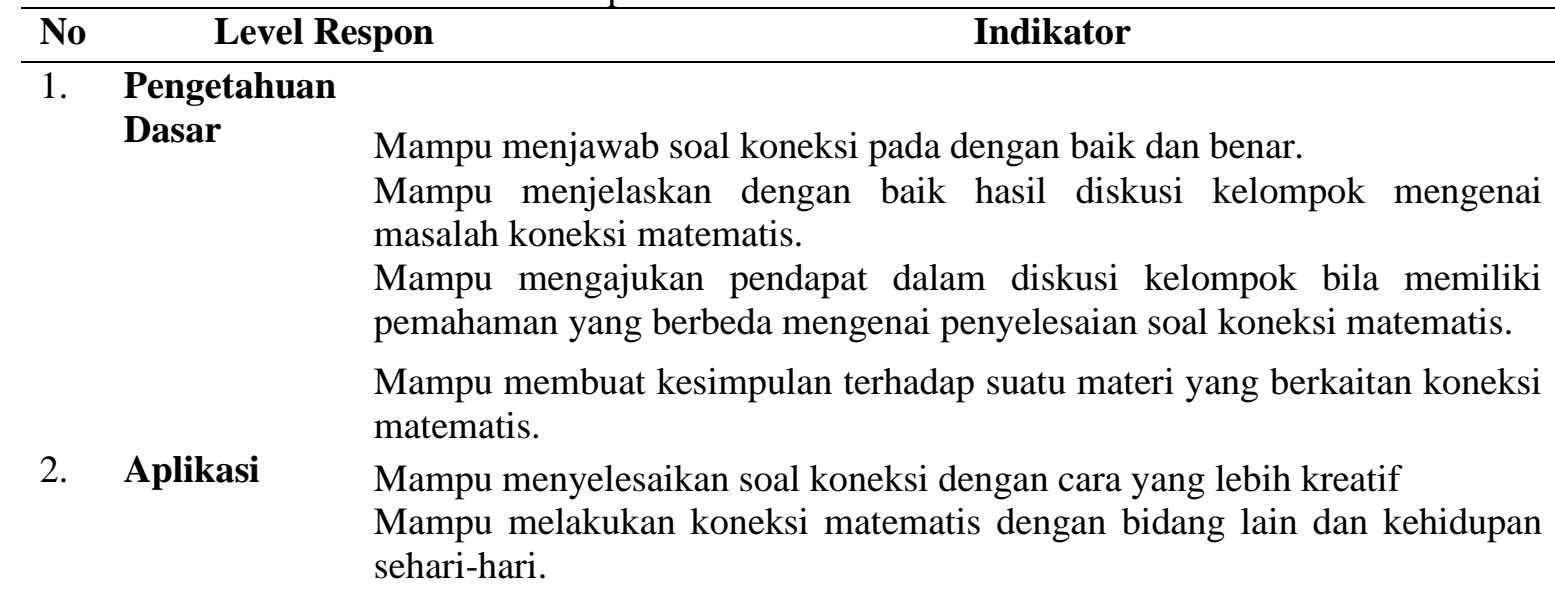


3. Integrasi

4. Dimensi Sosial

5. Peduli
Mampu membuat kesimpulan terhadap kumpulan fakta, prinsip, dan relasi dalam masalah koneksi matematis.

Mampu menunjukkan kemampuan representasi matematis yaitu bisa menyatakan ide matematis ke dalam bentuk simbol, gambar, tabel, atau persamaan matematis.

Mampu menghubungkan atau mengintegrasikan antara gambar dengan materi dalam menyelesaikan soal koneksi matematis.

Mampu melakukan koneksi antar materi dalam matematika saat mengerjakan soal-soal koneksi.

Mampu berinteraksi dengan teman saat menyelesaikan soal koneksi matematis.

Mampu menunjukkan sikap mengapresiasi pekerjaan teman.

Mampu menerima kelemahan orang lain dalam memahami suatu materi.

Mampu mendengarkan orang lain saat berdiskusi masalah koneksi matematis.

Mampu mengenali atau mengubah perasaan, minat, dan nilai seseorang.

Mampu menunjukkan sikap terbuka dan membantu orang lain yang kesulitan dalam memahami suatu materi

Mampu menunjukkan sikap aktif dalam diskusi dan kerja kelompok diskusi

Mampu menunjukkan sikap perhatian pada tujuan kelompok diskusi

Mampu mendahulukan kepentingan kelompok dari pada kepentingan pribadi

Mampu mencari solusi untuk mengatasi perbedaan pendapat atau pikiran dengan teman kelompok

Mampu mendorong orang lain untuk bekerja sama untuk menyelesaiakan masalah koneksi matematis

6. Metakognitif Mampu menyusun soal koneksi matematis secara mandiri

Mampu mengerjakan soal koneski secara mandiri

Mampu membangun pengetahuan secara mandiri

Mampu bertanya dan menjawab pertanyaan secara mandiri

\section{HASIL}

Penelitian ini dilaksanakan di program studi pendidikan matematika Unika Santu Paulus Ruteng dengan subyek penelitian merupakan mahasiwa tingkat 3B yang berjumlah 20 orang dengan rincian 12 orang mahasiswi dan 8 orang mahasiswa. Setiap mahasiswa dan mahasiswi mengerjakan soal kognitif dan metakognitif berupa soal-soal koneksi matematis serta mengisi angket untuk mengetahui respon pada dimensi peduli dan sosial masing-masing sebanyak dua kali. Level respon mahasiswa dan mahasiswi berdasarkan hasil jawaban tes dan angket dapat dilihat pada Tabel 2 dan Tabel 3.

Tabel 2. Level Respon Mahasiswa

\begin{tabular}{|c|c|c|c|c|c|}
\hline \multirow{2}{*}{ Level } & \multicolumn{2}{|c|}{ Tes } & \multicolumn{2}{|c|}{ Angket } & \multirow{2}{*}{ Jumlah } \\
\hline & Pertama & Kedua & Pertama & Kedua & \\
\hline \multicolumn{6}{|c|}{ Kognitif } \\
\hline Pengetahuan dasar & $18,26 \%$ & $18,58 \%$ & & & $18,42 \%$ \\
\hline Aplikasi & $12,36 \%$ & $13,22 \%$ & & & $12,79 \%$ \\
\hline Integrasi & $11,76 \%$ & $\begin{array}{c}12,68 \% \\
\text { Afektif }\end{array}$ & & & $12,22 \%$ \\
\hline Sosial & & & $23,09 \%$ & $23,46 \%$ & $23,28 \%$ \\
\hline Kepedulian & & & $22,18 \%$ & $22,50 \%$ & $22,34 \%$ \\
\hline \multicolumn{6}{|c|}{ Metakognitif } \\
\hline Metakognitif & $10,78 \%$ & $11,12 \%$ & & & $10,95 \%$ \\
\hline
\end{tabular}


Tabel 3. Level Respon Mahasiswi

\begin{tabular}{|c|c|c|c|c|c|}
\hline \multirow{2}{*}{ Level } & \multicolumn{2}{|c|}{ Tes } & \multicolumn{2}{|c|}{ Angket } & \multirow{2}{*}{ Jumlah } \\
\hline & Pertama & Kedua & Pertama & Kedua & \\
\hline \multicolumn{6}{|c|}{ Kognitif } \\
\hline Pengetahuan dasar & $18,52 \%$ & $19,36 \%$ & & & $18,94 \%$ \\
\hline Aplikasi & $13,97 \%$ & $13,35 \%$ & & & $13,16 \%$ \\
\hline Integrasi & $10,89 \%$ & $11,57 \%$ & & & $11,23 \%$ \\
\hline & & Afektif & & & \\
\hline Sosial & & & $23,36 \%$ & $24,38 \%$ & $23,87 \%$ \\
\hline Peduli & & & $22,58 \%$ & $22,98 \%$ & $22,78 \%$ \\
\hline \multicolumn{6}{|c|}{ Metakognitif } \\
\hline Metakognitif & $9,78 \%$ & $10,26 \%$ & & & $10,02 \%$ \\
\hline
\end{tabular}

Berdasarkan Tabel 2 dan Tabel 3 diperoleh pertama, respon mahasiswa pada level pengetahuan dasar pada tes pertama dan kedua mengalami peningkatan sebesar 0,32\% sedangkan peningkatan respon mahasiswi pada level yang sama sebesar 0,84\%. Secara keseluruhan respon mahasiswa pada level pengetahuan dasar sebesar 18,42\% sedangkan respon mahasiswi sebesar 18,94\% dengan selisih sebesar $0,52 \%$. Kedua, respon mahasiswa pada level aplikasi pada tes pertama dan kedua mengalami peningkatan sebesar $0,86 \%$ sedangkan respon mahasiswi pada level yang sama mengalami peningkatan sebesar $0,38 \%$. Secara keseluruhan respon mahasiswa pada level aplikasi sebesar 12,79\% sedangkan respon mahasiswi sebesar 13,16\%, dengan selisih sebesar 0,37\%. Ketiga, respon mahasiswa pada level integrasi pada tes pertama dan kedua mengalami peningkatan sebesar $0,92 \%$ dan respon mahasiswi pada level yang sama mengalami peningkatan sebesar 0,68\%. Secara keseluruhan respon mahasiswa pada level integrasi sebesar $12,22 \%$ sedangkan respon mahasiswi sebesar $11,23 \%$, dengan selisih sebesar $0,99 \%$.

Keempat, respon mahasiswa pada dimensi sosial pada angket pertama dan kedua mengalami peningkatan sebesar $0,37 \%$ sedangkan respon mahasiswi pada dimensi yang sama mengalami peningkatan sebesar $1,02 \%$. Secara keseluruhan respon mahasiswi pada dimensi sosial sebesar 23,87\% sedangkan respon mahasiswa sebesar 23,28\%. Jadi, selisih respon mahasiswi dan mahasiswa pada dimensi sosial sebesar 0,59\%. Kelima, respon mahasiswa pada level kepedulian pada angket pertama dan kedua mengalami peningkatan sebesar $0,32 \%$ sedangkan respon mahasiswi pada level yang sama mengalami peningkatan sebesar $0,40 \%$. Secara keseluruhan respon mahasiswi pada level kepedulian sebesar 22,78\% sedangkan respon mahasiswa sebesar 22,34\%, dengan selisih sebesar $0,44 \%$.

Keenam, respon mahasiswa pada level metakognitif pada tes pertama dan tes kedua mengalami peningkatan yaitu sebesar $0,34 \%$ sedangkan respon mahasiswi pada level yang sama mengalami peningkatan sebesar $0,48 \%$. Secara keseluruhan respon mahasiswa pada level metakognitif sebesar 10,95\% sedangkan respon mahasiswi sebesar 10,02\%, dengan selisih sebesar $0,93 \%$.

\section{PEMBAHASAN}

\section{Level Pengetahuan Dasar}

Respon mahasiswa pada level pengetahuan dasar untuk tes pertama sebesar 18,26\% dimana mahasiswa sudah mampu menjawab soal koneksi matematis dengan benar, mampu menjelaskan hasil diskusi dengan baik serta sebagian besar sudah mampu mengajukan pendapat dalam diskusi kelompok, namun masih ada mahasiswa yang belum mampu membuat kesimpulan terhadap materi koneksi matematis dan pada tes kedua sebesar 18,58\% dengan peningkatan sebesar 0,32\%, dimana mahasiswa mampu menjawab soal koneksi dengan baik dan benar, mampu melakukan diskusi kelompok, mengajukan pendapat saat diskusi kelompok serta sebagian mampu membuat kesimpulan terhadap materi koneksi matematis. Berdasarkan uraian tersebut terlihat bahwa ada perubahan respon 
mahasiswa pada level pengetahuan dasar, dimana respon mahasiswa pada tes kedua lebih banyak daripada tes pertama terutama dalam membuat kesimpulan terhadap materi koneksi matematis.

Respon mahasiswi pada level pengetahuan dasar untuk tes pertama sebesar 18,52\% dimana mahasiswi sudah mampu menjawab soal koneksi matematis dengan benar, mampu menjelaskan hasil diskusi dengan baik serta mampu mengajukan pendapat dalam diskusi kelompok, namun hanya beberapa yang mampu membuat kesimpulan terhadap materi koneksi matematis sedangkan pada tes kedua respon mahasiswi sebesar $19,36 \%$ dengan peningkatan sebesar $0,84 \%$, dimana mahasiswi telah mampu menjawab soal koneksi dengan baik dan benar, mampu melakukan diskusi kelompok, mengajukan pendapat saat diskusi kelompok serta sebagian besar mampu membuat kesimpulan terhadap materi koneksi matematis. Berdasarkan uraian tersebut terlihat bahwa pada tes kedua respon mahasiswi lebih banyak daripada tes pertama.

Secara keseluruhan respon mahasiswa pada level pengetahuan dasar sebesar 18,42\% sedangkan respon mahasiswi sebesar $18,94 \%$, dengan selisih sebesar $0,52 \%$. Hal ini menunjukkan bahwa pada level pengetahuan dasar respon mahasiswi lebih banyak daripada mahasiswa, dimana mahasiswi lebih berperan aktif untuk menjawab soal koneksi matematis, menjelaskan dan mengajukan pendapat saat diskusi, serta mampu membuat kesimpulan terhadap materi koneksi matematis. Hasil ini didukung oleh hasil penelitian Triyadi (2013) yang menyatakan bahwa perempuan memiliki kemampuan koneksi, kemampuan komunikasi, dan kemampuan penalaran matematis yang lebih menonjol bila dibandingkan dengan laki-laki.

\section{Aplikasi}

Respon mahasiswa pada level aplikasi dalam tes pertama sebesar 12,36\% dimana pada tes yang pertama mahasiswa sudah mampu menyelesaikan soal koneksi matematis secara lebih kreatif, mampu membuat kesimpulan terhadap kumpulan fakta, prinsip, dan relasi dalam koneksi matematis, namun sebagian besar belum dapat melakukan koneksi matematika dengan bidang lain dan dengan kehidupan sehari-hari, sedangkan respon mahasiswa pada tes yang kedua sebesar 13,22\% dengan peningkatan sebesar $0,86 \%$ dimana mahasiswa sudah mampu menyelesaikan soal koneksi matematis secara lebih kreatif, mampu membuat kesimpulan terhadap kumpulan fakta, prinsip, dan relasi pada masalah koneksi matematis, dan mampu melakukan koneksi matematika dengan bidang lain, dan sebagian mahasiswa dapat melakukan koneksi matematika dengan kehidupan sehari-hari. Berdasarkan uraian tersebut terlihat bahwa respon mahasiswa pada tes kedua lebih banyak dari tes pertama terutama dalam melakukan koneksi matematika dengan kshidupan sehari-hari.

Respon mahasiswi pada level aplikasi dalam tes pertama sebesar 12,97\% dimana pada tes yang pertama mahasiswa sudah mampu menyelesaikan soal koneksi matematis secara lebih kreatif, mampu membuat kesimpulan terhadap kumpulan fakta, prinsip, dan relasi dalam koneksi matematis, namun sebagian mahasiswi belum dapat melakukan koneksi matematika dengan bidang lain dan dengan kehidupan sehari-hari, sedangkan respon mahasiswi pada tes yang kedua sebesar 13,35\% dengan peningkatan sebesar $0,38 \%$ dimana mahasiswi sudah mampu menyelesaikan soal koneksi matematis secara lebih kreatif, mampu membuat kesimpulan terhadap kumpulan fakta, prinsip, dan relasi pada masalah koneksi matematis, dan mampu melakukan koneksi matematika dengan bidang lain dan dengan kehidupan sehari-hari. Berdasarkan uraian tersebut terlihat bahwa pada level aplikasi respon mahasiswi pada tes kedua lebih banyak dari tes pertama terutama dalam melakukan koneksi matematika dengan bidang lain dan kehidupan sehari-hari.

Secara keseluruhan respon mahasiswa pada level aplikasi sebesar 12,79\% sedangkan respon mahasiswi sebesar $13,16 \%$, dengan selisih sebesar $0,37 \%$. Hal ini menunjukkan bahwa pada level aplikasi respon mahasiswi lebih banyak daripada mahasiswa, dimana mahasiswi memiliki respon yang paling banyak dalam melakukan koneksi matematika baik dengan bidang lain maupun dengan kehidupan sehari-hari. Hasil ini didukung oleh hasil penelitian Triyadi (2013) yang menyatakan bahwa perempuan memiliki kemampuan koneksi yang lebih menonjol bila dibandingkan dengan laki-laki, baik kemampuan dalam melakukan koneksi inter dan antar topik dalam matematika, maupun koneksi matematika dengan bidang lain atau koneksi matematika dengan kehidupan sehari-hari.

\section{Integrasi}

Respon mahasiswa pada level integrasi untuk tes pertama sebesar 11,76\% dimana mahasiswa mampu melakukan representasi matematis yaitu mampu menyatakan idea atau masalah matematis ke dalam persamaan matematis, mengintegrasikan antara gambar dengan materi, namun sebagian besar mahasiswa belum mampu melakukan koneksi antar materi, sedangkan respon mahasiswa pada tes 
kedua sebesar $12,68 \%$ dengan peningkatan sebesar $0,92 \%$ dimana mahasiswa telah mampu melakukan representasi matematis, mengintegrasikan antara gambar dengan materi, serta separuh mahasiswa mampu melakukan koneksi antar materi. Berdasarkan uraian tersebut terlihat ada peningkatan respon mahasiswa pada level aplikasi terutama dalam melakukan koneksi antar materi persamaan diferensial dengan masalah nilai awal.

Respon mahasiswi pada level integrasi untuk tes pertama sebesar 10,89\% dimana mahasiswi mampu melakukan representasi matematis yaitu mampu menyatakan idea atau masalah matematis ke dalam persamaan matematis, mengintegrasikan antara gambar dengan materi, namun mahasiswi belum mampu melakukan koneksi antar materi, sedangkan respon mahasiswi pada tes kedua sebesar $11,57 \%$ dengan peningkatan sebesar $0,68 \%$ dimana mahasiswa telah mampu melakukan representasi matematis, mengintegrasikan antara gambar dengan materi, serta beberapa mahasiswi mampu melakukan koneksi antar materi. Berdasarkan uraian tersebut terlihat bahwa pada level aplikasi respon mahasiswi pada tes kedua lebih banyak bila dibandingkan dengan tes pertama.

Secara keseluruhan respon mahasiswa pada level integrasi sebesar $12,22 \%$ sedangkan respon mahasiswi sebesar 11,23\%, dengan selisih sebesar 0,99\%. Hal ini menunjukkan bahwa pada level integrasi respon mahasiswa lebih banyak daripada mahasiswi, dimana mahasiswa berperan lebih banyak bila dibandingkan dengan mahasiswi terutama dalam melakukan representasi matematis berupa kemampuan menyatakan ide-ide matematis ke dalam gambar atau tabel dan juga melakukan koneksi antar materi persamaan diferensial dan masalah nilai awal. Hal ini sejalan dengan hasil penelitian Umaroh \& Pujiastuti (2020) yang menyatakan bahwa laki-laki mampu melakukan representasi visual dalam bentuk gambar, grafik dan tabel sedangkan perempuan tidak dapat melakukan representasi visual.

\section{Dimensi Sosial}

Respon mahasiswa pada dimensi sosial untuk angket pertama yaitu sebesar 23,09\% dimana mahasiswa mampu berinteraksi dengan teman saat berdiskusi, menerima kelemahan orang lain, dan mendengarkan orang lain saat mengerjakan soal-soal koneksi matematis, namun sebagian besar belum mampu menunjukkan apresiasi terhadap hasil pekerjaan teman, sedangkan respon pada angket kedua sebesar $24,46 \%$ dengan peningkatan sebesar $0,37 \%$ dimana pada angket kedua ini mahasiswa sudah bisa berinteraksi dengan teman saat berdiskusi, menerima kelemahan orang lain, dan mendengarkan orang lain saat mengerjakan masalah koneksi matematis, dan sebagian mahasiswa telah mampu menunjukkan apresiasi terhadap hasil pekerjaan teman. Berdasarkan uraian tersebut terlihat bahwa ada perubahan respon mahasiswa pada dimensi sosial terutama pada sikap apresiasi pekerjaan teman.

Respon mahasiswi pada dimensi sosial untuk angket pertama yaitu sebesar $23,36 \%$ dimana mahasiswa mampu berinteraksi dengan teman saat berdiskusi, menerima kelemahan orang lain, dan mendengarkan orang lain saat mengerjakan soal-soal koneksi matematis, namun sebagian mahasiswi belum mampu menunjukkan apresiasi terhadap hasil pekerjaan teman, sedangkan respon pada angket kedua sebesar 24,38\% dengan peningkatan sebesar 1,02\% dimana pada angket kedua ini mahasiswi mampu berinteraksi dengan teman diskusi, menerima kelemahan orang lain, dan mendengarkan orang lain saat mengerjakan masalah koneksi matematis, dan mampu menunjukkan apresiasi terhadap hasil pekerjaan teman. Berdasarkan uraian tersebut terlihat bahwa respon mahasiswi pada angket kedua lebih banyak bila dibandingkan dengan angket pertama.

Secara keseluruhan respon mahasiswa pada dimensi sosial sebesar $23,28 \%$ sedangkan respon mahasiswi sebesar $23,87 \%$, dengan selisih sebesar $0,59 \%$. Hal ini menunjukkan bahwa pada dimensi sosial respon mahasiswi lebih banyak bila dibandingkan dengan mahasiswa terutama dalam aspek mengapresiasi hasil pekerjaan teman. Hal ini didukung oleh penelitian Prawitasari \& Kahn (1985) yang menyatakan bahwa wanita cendrung lebih hangat, emosional, peka dan mentaati aturan, sedangkan laki-laki cendrung lebih stabil, dominan, dan impulsif.

\section{Level Kepedulian}

Respon mahasiswa pada aspek kepedulian untuk angket pertama yaitu sebesar 22,18\% dimana mahasiswa mampu memahami perasaan orang lain, menunjukkan sikap terbuka, aktif dan perhatian pada saat diskusi, mendahulukan kepentingan kelompok. Namun, belum mampu menunjukkan sikap mendorong kerjasama dan mencari solusi terhadap perbedan pendapat dan pikiran dalam kelompok. Respon mahasiswa pada angket kedua sebesar 22,50\% dengan peningkatan sebesar 0,37\% dimana mahasiswa mampu memahami perasaan orang lain, menunjukkan sikap terbuka, aktif dan perhatian saat diskusi, mendahulukan kepentingan kelompok serta beberapa mahasiswa mampu menunjukkan 
sikap mendorong kerjasama dan mencari solusi terhadap perbedan pendapat dan pikiran dalam kelompok. Berdasarkan uraian tersebut terlihat bahwa dalam aspek kepedulian respon mahasiswa ada peningkatan yang tidak terlalu signifikan terutama dalam mendorong kerjasama dan mencari solusi terhadap perbedan pendapat dan pikiran dalam kelompok.

Respon mahasiswi pada aspek kepedulian untuk angket pertama yaitu sebesar 22,58\% dimana mahasiswa mampu memahami perasaan orang lain, menunjukkan sikap terbuka, aktif dan perhatian pada saat diskusi, mendahulukan kepentingan kelompok serta beberapa mampu menunjukkan sikap mendorong kerjasama dan mencari solusi terhadap perbedan pendapat dan pikiran dalam kelompok. Respon mahasiswi pada angket kedua sebesar 22,98\% dengan peningkatan sebesar $0,40 \%$ dimana mahasiswa mampu memahami perasaan orang lain, menunjukkan sikap terbuka, aktif dan perhatian saat diskusi, mendahulukan kepentingan kelompok serta sebagian mahasiswi mampu menunjukkan sikap mendorong kerjasama dan mencari solusi terhadap perbedan pendapat dan pikiran dalam kelompok. Berdasarkan uraian tersebut terlihat bahwa dalam aspek kepedulian respon mahasiswi lebih banyak pada angket kedua bila dibandingkan dengan angket pertama terutama dalam mendorong kerjasama dan mencari solusi terhadap perbedan pendapat dan pikiran dalam kelompok.

Secara keseluruhan respon mahasiswa pada aspek kepedulian sebesar 22,34\% sedangkan respon mahasiswi sebesar $22,78 \%$, dengan selisih sebesar $0,44 \%$. Hal ini menunjukkan bahwa pada aspek kepedulian respon mahasiswi lebih banyak bila dibandingkan dengan mahasiswa terutama pada aspek mendorong kerjasama dan mencari solusi terhadap perbedan pendapat dan pikiran dalam kelompok. Hal ini sejalan dengan hasil penelitian Rhee dkk (2013) yang menyatakan bahwa perempuan memiliki kepedulian yang lebih tinggi daripada laki-laki karena perempuan memiliki kemampuan verbal yang lebih baik sehingga mudah untuk membangun kerjasama dengan orang lain. Penelitian Eisenberg dan Fabes (1990) juga menunjukkan bahwa anak perempuan berperilaku lebih ramah dan memiliki perhatian kepada orang lain daripada yang ditunjukkan laki-laki.

\section{Metakognitif}

Respon mahasiswa pada level metakognitif untuk tes pertama sebesar yaitu $10,78 \%$ dimana mahasiswa mampu mengerjakan soal-soal koneksi secara mandiri, mampu bertanya dan menjawab sendiri. Namun sebagian besar belum mampu membangun pengetahuan dan menyusun soal-soal koneksi secara mandiri. Respon mahasiswa pada tes kedua sebesar 11,12\% dengan peningkatan sebesar $0,34 \%$ dimana mahasiswa mampu mengerjakan soal-soal koneksi secara mandiri, mampu bertanya dan menjawab sendiri serta sebagian mahasiswa mampu membangun pengetahuan dan menyusun soal-soal koneksi secara mandiri.

Respon mahasiswi pada level metakognitif untuk tes pertama sebesar 9,78\% dimana mahasiswi mampu mengerjakan soal-soal koneksi secara mandiri, mampu bertanya dan menjawab sendiri. Namun belum mampu membangun pengetahuan dan menyusun soal-soal koneksi secara mandiri. Respon mahasiswi pada tes kedua sebesar 10,26\% dengan peningkatan sebesar 0,48\% dimana mahasiswa mampu mengerjakan soal-soal koneksi secara mandiri, mampu bertanya dan menjawab sendiri serta beberapa mahasiswi mampu membangun pengetahuan dan menyusun soal-soal koneksi secara mandiri.

Secara keseluruhan respon mahasiswa pada level metakognitif sebesar 10,95\% sedangkan respon mahasiswi sebesar $10,02 \%$, dengan selisih sebesar $0,93 \%$. Hal ini menunjukkan bahwa pada level metakognitif respon mahasiswa lebih banyak daripada mahasiswi, dimana mahasiswa berperan lebih banyak bila dibandingkan dengan mahasiswi terutama kemampuan membangun pengetahuan dan menyusun soal-soal koneksi secara mandiri. Hal ini didukung oleh penelitian Pai'pinan (2015) yang menyatakan mahasiswa dapat mengontrol pekerjaannya dengan baik selama menyelesaikan masalah sedangkan mahasiswi kurang teliti sehingga tidak dapat mengontrol pekerjaannya dengan baik.

\section{SIMPULAN DAN SARAN}

Respon mahasiswa dalam mengerjakan soal-soal koneksi matematis memberikan gambaran secara detail mengenai respon aktif mahasiswa dan mahasiswi baik aspek kognitif antara lain level pengetahuan dasar, aplikasi, dan integrasi, aspek afektif berupa dimensi sosial dan kepedulian, dan juga aspek metakognitif. Respon mahasiswi dan mahasiswi pada level pengetahuan dasar sebesar $18,94 \%$ dan $18,42 \%$, dimana mahasiswi lebih berperan aktif untuk menjawab soal koneksi matematis, 
menjelaskan dan mengajukan pendapat saat diskusi, serta mampu membuat kesimpulan terhadap materi koneksi matematis. Respon mahasiswi dan mahasiswa pada level aplikasi sebesar $13,16 \%$ dan $12,79 \%$, dimana mahasiswi memiliki respon yang paling banyak dalam melakukan koneksi matematika baik dengan bidang lain maupun dengan kehidupan sehari-hari. Sedangkan pada level integrasi respon mahasiswa dan mahasiswi sebesar $12,22 \%$ dan $11,23 \%$, dimana pada level ini mahasiswa berperan lebih banyak bila dibandingkan dengan mahasiswi terutama dalam melakukan representasi matematis berupa kemampuan menyatakan ide-ide matematis ke dalam ekspresi atau simbol matematis dan juga melakukan koneksi antar materi persamaan diferensial dan masalah nilai awal. Respon mahasiswi dan mahasiswa pada dimensi sosial sebesar 23,87\% dan 23,28\%, dimana respon mahasiswi lebih banyak bila dibandingkan dengan mahasiswa terutama dalam aspek mengapresiasi hasil pekerjaan teman. Sedangkan pada aspek kepedulian respon mahasiswi dan mahasiswa sebesar 22,78\% dan 22,34\%. Hal ini menunjukkan bahwa pada aspek kepedulian respon mahasiswi lebih banyak bila dibandingkan dengan mahasiswa terutama pada aspek mendorong kerjasama dan mencari solusi terhadap perbedan pendapat dan pikiran dalam kelompok. Terakhir, respon mahasiswa dan mahasiswi pada level metakognitif sebesar 10,95\% dan 10,02\%. Hal ini menunjukkan bahwa pada level metakognitif respon mahasiswa lebih banyak daripada mahasiswi, dimana mahasiswa berperan lebih banyak bila dibandingkan dengan mahasiswi terutama kemampuan membangun pengetahuan dan menyusun soal-soal koneksi secara mandiri. Respon mahasiswa pada aspek kognitif, afektif, maupun metakognitif memberikan gambaran bagi pendidik agar memperhatikan kemampuan dan sikap siswa dalam membangun pengetahuan secara mandiri pada suatu materi pelajaran. Penelitian lanjutan perlu dilakukan untuk mengetahui respon mahasiswa pada kemampuan matematis lain melalui taksonomi Fink.

\section{DAFTAR RUJUKAN}

Chaplin, J. P. (2004). Kamus Lengkap Psikologi,(Terjemahan Kartini dan Kartono). Jakarta: Raja Grafindo Persada.

Ekawati, R., Junaedi, I., \& Nugroho, S. E. (2013). Studi respon siswa dalam menyelesaikan soal pemecahan masalah matematika berdasarkan taksonomi SOLO. Unnes Journal of Mathematics Education Research, 2(2).

Eisenberg, N., \& Fabes, R. A. (1990). Empathy: Conceptualization, measurement, and relation to prosocial behavior. Motivation and Emotion, 14(2), 131-149.

Fink, L. D. (2013). Creating significant learning experiences: An integrated approach to designing college courses. John Wiley \& Sons.

Hamalik, O. (2011). Proses belajar mengajar. Jakarta: Bumi Aksara.

Hudojo, H. (1988). Mengajar belajar matematika. Jakarta: Depdikbud.

Latifah, I. U. (2017). Pengembangan instrumen penilaian hasil belajar Matematika berbasis Taksonomi Fink (Doctoral dissertation, UIN Sunan Ampel Surabaya).

Linto, R. L. (2012). Kemampuan koneksi matematis dan metode pembelajaran quantum teaching dengan peta pikiran. Jurnal Pendidikan Matematika, 1(1).

Pai'pinan, M. (2015). Profil Metakognisi Mahasiswa Calon Guru Matematıka dalam Menyelesa1kan Masalah Terbuka Geometrı Ditinjau dari Perbedaan Gender. Jurnal Ilmıah Matematıka dan Pembelajarannya, 1(1).

Prawitasari, J. E., \& Kahn, M. W. (1985). Personality differences and sex similarities in American and Indonesian college students. The Journal of Social Psychology, 124, 703-708.

Ramdani, Y. (2012). Pengembangan instrumen dan bahan ajar untuk meningkatkan kemampuan komunikasi, penalaran, dan koneksi matematis dalam konsep integral. Jurnal Penelitian Pendidikan, 13(1), 44-52.

Rhee, S. H., Boeldt, D. L., Friedman, N. P., Corley, R. P., Hewitt, J. K., Young, S. E., ... \& ZahnWaxler, C. (2013). The role of language in concern and disregard for others in the first years of life. Developmental Psychology, 49(2), 197.

Simanjuntak, S. D., \& Imelda, I. (2018). Respon Siswa terhadap Pembelajaran Matematika Realistik dengan Konteks Budaya Batak Toba. MES: Journal of Mathematics Education and Science, 4(1), 81-88.

Suryadi, D. (2011). Kesetaraan Didactical Design Research (DDR) Dengan Matematika Realistik Dalam Pengembangan Pembelajaran Matematika. Jurnal FMIPA UPI Bandung. 
Triyadi, R. (2013). Kemampuan matematis ditinjau dari perbedaan gender (Doctoral dissertation, Universitas Pendidikan Indonesia).

Wagner, T. (2012). Creating innovators: The making of young people who will change the world. Simon and Schuster.

Umaroh, U., \& Pujiastuti, H. (2020). Analisis Kemampuan Representasi Matematis Siswa dalam Mengerjakan Soal PISA Ditinjau dari Perbedaan Gender. Jurnal Pendidikan Matematika Raflesia, 5(2), 40-53.

Wijaya, A. (2012). Pendidikan matematika realistik suatu alternatif pendekatan pembelajaran matematika. Yogyakarta: Graha Ilmu. 